\title{
Božena Vranješ-Šoljan, Dalmacija. Stoljeće povijesnih $i$ demografskih mijena 1815-1918, EDUCA, Zagreb 2021, ss. 516.
}

doi.org/10.14746/bp.2021.28.31

Dalmacja w XIX wieku, chociaż była najmniej zaludnioną i jedną z najgorzej rozwiniętych ziem wchodzących w skład Monarchii Habsburgów, miała dla Wiednia duże znaczenie strategiczne i gospodarcze. Wraz z Istrią pełniła rolę „okna na świat” dzięki bezpośredniemu sąsiedztwu Adriatyku. Austriackie flagi po raz pierwszy załopotały na najważniejszych budynkach publicznych w tym rejonie w 1797 roku, gdy na mocy pokoju w Campio Formio Francja przekazała Habsburgom większość ziem, należących do zlikwidowanej wówczas Republiki Wenecji. Okres ten, trwający do 1806 roku, zakończył się zajęciem wybrzeża adriatyckiego przez Francję napoleońską, która wkrótce utworzyła tam Prowincje Iliryjskie. Po epoce napoleońskiej Cesarstwo Austriackie w osobie hrabiego Klemensa Metternicha domagało się podczas Kongresu Wiedeńskiego przekazania władzy nad Dalmacją, gdzie od pewnego czasu stacjonowały już wojska habsburskie. Ponoć Austria była nawet skłonna zrzec się władzy nad Galicą w zamian za wybrzeże dalmatyńskie. Szczęśliwie dla niej udało się zatrzymać zarówno większość terenów wchodzących niegdyś w skład Rzeczypospolitej, jak i zagarnąć Prowincje Iliryjskie. Wkrótce po Kongresie Wiedeńskim podzielono je na Królestwo Dalmacji i Królestwo Istrii, które istniało do 1849 roku. W 1860 roku obszar ten przemiano na Margrabstwo Istrii ${ }^{1}$.

Dzieje Królestwa Dalmacji w latach 1815-1918 są tematem monografii naukowej autorstwa uznanej chorwackiej historyczki Boženy Vranješ-Šoljan. Publikacja ta pretenduje do miana kompleksowej prezentacji dziejów regionu i jest zestawiana $\mathrm{z}$ dotychczasowymi dokonaniami $\mathrm{w}$ tym zakresie, np. $\mathrm{z}$ dwutomową monografią Grge Novaka czy wydanym sześć lat temu dziełem Dalmacija i Istra u 19. stoljeću, autorstwa Marka Troglicia i Nevia Šeticia ${ }^{2}$. Autorka za główny cel obrała szczegółową analizę danych statystycznych, zebranych na podstawie spisów powszechnych ludności, przeprowadzonych przez władze austriackie w drugiej połowie XIX wieku. Podobne badania prowadziła ona już wcześniej w odniesieniu do badań nad historią społeczną z obszaru tzw. Banowiny ${ }^{3}$.

Recenzowana książka otrzymała pozytywne opinie od dwóch uznanych specjalistów w zakresie historii Dalmacji, Stijepana Čosicia i Marka Trogrlicia. Liczy 515 stron, jest podzielona na siedem rozdziałów i zaopatrzona w indeks geograficzny oraz

1 Por. L. Wolff, The idea of Galicia. History and Fantasy in Habsburg Political Culture, California 2010, s. 64; M. Senkowska-Gluck, Rządy napoleońskie w Ilirii 1809-1813, Wrocław 1983; A. Cetnarewicz, Odrodzenie narodowe w Istrii w latach 1860-1907, Kraków 2010, s. 32.

2 G. Novak, Prošlost Dalmacije, t. 1-2, Zagreb 1944; M. Trogrlić, N. Šetić, Dalmacija i Istra u 19. stoljeću, Zagreb 2016.

3 B. Vranješ-Šoljan Demografska slika Banske Hrvatske u kontekstu društveno-povijesnih promjena od 1850. do 1910, Zagreb 2009. 
osobowy. W bibliografii znalazły się wszystkie najważniejsze publikacje, jakie dotychczas pojawiły się na temat dziejów Dalmacji na chorwackim i niemieckim rynku naukowo-wydawniczym. Także w sprawach źródłowych autorka koncentruje się wyłącznie na materiałach $\mathrm{z}$ tych kręgów językowych. W badaniach wykorzystała różnego typu materiały sprawozdawczo-administracyjne i pamiętnikarskie. Literatura pamiętnikarska jest szczególnie ważna dla charakterystyki okresu sprzed 1850 roku, jako że władze austriackie prowadziły spisy powszechne w Dalmacji dopiero od połowy XIX wieku. Co ciekawe, autorka w ogóle nie wykorzystała źródeł pochodzących w archiwów w Zadarze czy Splicie. Nie wiadomo, co było tego przyczyną, bo nie zostało wyjaśnione w książce. Ponadto trudno zrozumieć, dlaczego zabrakło w niej spisu licznych tabel i wykresów, uwzględnionych w monografii. Jest to poważne niedociągnięcie, które utrudnia korzystanie z przytoczonych informacji. Czytelnik musi przerzucać kolejne strony książki, bez możliwości zorientowania się w strukturze zebranego i przedstawionego materiału statystycznego.

Układ książki jest stricte chronologiczny, a narracja koncentruje się na kwestiach demograficznych, w odwołaniu do danych statystycznych z poszczególnych lat (1851, $1857,1869,1880)$. Statystyki, wykorzystane przez autorkę, stanowią punkt wyjścia dla rozważań, dotyczących zjawisk determinujących charakterystykę społeczno-gospodarczą i polityczną regionu ${ }^{4}$. Dużą uwagę poświęciła ona także ukazaniu pozycji Dalmacji w kontekście spraw określających relacje w ramach całej monarchii habsburskiej.

W pierwszym, najbardziej obszernym rozdziale B. Vranješ-Šoljan zaprezentowała rolę, jaką Dalmacja odegrała w Monarchii Habsburgów od chwili jej przyłączenia do połowy XIX wieku. Przeanalizowane zostały dwa dokumenty o charakterze statystycznym z 1803 i 1817, tzw. materiały Bernarda Stulli i spis autorstwa Frane Carrary z 1843 roku. B. Vranješ-Šoljan przyznaje, że dane pochodzące z tych źródeł budzą wątpliwości wielu badaczy, jednocześnie uważa jednak, że na tej podstawie można wysnuć wiarygodne naukowo wnioski na temat ogólnego charakteru zmian demograficznych w Dalmacji. Autorka zestawia je z informacjami o innych krajach, znajdujących się w monarchii habsburskiej. Oprócz danych liczbowych przytacza interesujące informacje, np. o strukturze wieku, dotyczącej stosunkowo późno podejmowanych w Dalmacji decyzji o zamążpójściu. Ciekawie brzmią wnioski na temat zmian gospodarczych w regionie, chociażby w dziedzinie winiarstwa, które w czasach austriackich intensywnie się rozwijało. Autorka odnotowuje zdecydowany progres w dziedzinie służby zdrowia, ale i relatywizuje jego dynamikę zauważając, że poziom opieki zdrowotnej był w Dalmacji na znacznie niższym poziomie niż w najlepiej rozwiniętych cywilizacyjnie regionach cesarstwa. Przytoczone przez nią dane o sprawach gospodarczych korespondują z informacjami na temat ówczesnych procesów narodowotwórczych. Wśród mieszkańców regionu, najszybciej w miastach, gdzie żyli po-

4 B. Vranješ-Šoljan, Stanovništvo gradova banske Hrvatske na prijelazu stoljeća: socijalno-ekonomski sastav i vodeći slojevi 1890-1914, Zagreb 1991. 
tomkowie dawnych rodów patrycjuszowskich, zaczęły się wówczas wyodrębniać poszczególne społeczności etniczne, Włosi, Chorwaci czy Serbowie 5 .

W rozdziale drugim znalazła się szczegółowa analiza i interpretacja urzędowych spisów ludności z lat 1851 i 1857 . Obraz Dalmacji, stworzony na podstawie tych źródeł, jest zróżnicowany i zniuansowany, ale i nacechowany austriackim duchem. Władze państwowe z powodów politycznych wprowadzały do spisów odgórnie narzucone schematy. I tak, w spisie z 1851 roku, który był realizowany pod czujnym okiem wiedeńskich wysłanników Petera Judsona i Karla von Czöringa, określenie narodowość było używane w odniesieniu do osób, które nie zawsze rozumiały, o co w nim chodziło. Co więcej rachmistrzowie często nie pytali indywidualnie o przynależność narodową i wpisywali do metryki informację uzyskane od głów rodzin lub osób uznawanych za liderów danej społeczności, np. sołtysów. W konsekwencji otrzymane wyniki bardzo często odstawały od rzeczywistości. Pomimo tych problemów, na podstawie spisu z 1857 roku autorka przedstawiła wiele interesujących danych o charakterze i zakresie migracji wewnętrznych oraz zewnętrznych. W oparciu o nie można zanegować np. tezę, często podnoszoną z historiografii jugosłowiańskiej, jakoby administracja cywilna w Dalmacji znajdowała się pod dużym wpływem włoskiej społeczności ${ }^{6} . Z$ danych statystycznych wyłania się także permanentny regres komunikacyjny w regionie. Pomimo rozwiniętego transportu morskiego, Dalmacja znajdowała się na początku lat sześćdziesiątych XIX wieku na przedostatnim miejscu w cesarstwie pod względem długości torów kolejowych, wyprzedzając w tej kwestii jedynie pobliskie Pogranicze Wojskowe.

Rozdział trzeci i czwarty zdominowały rozważania o kwestiach politycznych, autorka przeanalizowała także rezultaty spisów powszechnych z lat 1869 i 1880. $\mathrm{W}$ tym przypadku materiał statystyczny jest zwykle intepretowany za pomocą swoistej kompilacji wniosków zebranych na podstawie wcześniejszych ustaleń naukowych, obecnych w historiografii chorwackiej ${ }^{7}$. Autorka poruszyła wątki dotyczące wspólnych działań chorwacko-serbskich przeciwko ekspansji Włoch, opisała zróżnicowane stanowiska miejscowych środowisk politycznych wobec idei zjednoczeniowej z Banowiną Chorwacji. Szczególnie interesujące wnioski odnoszą się do spisu z 1880 roku, który w porównaniu z wcześniejszymi był najlepiej przeprowadzony i opracowany. Na jego podstawie w historiografii dowodzono, że struktury społeczne ówczesnej Dalmacji uległy pod koniec XIX wieku daleko posuniętej modernizacji. Autorka wykazuje, że twierdzenie to nie było uzasadnione naukowo, ponieważ o pojawieniu się większości nowych zawodów w spisie zadecydowała korekta wcześniej stosowanej terminologii, a nie inwestycje państwowe czy prywatne w regionie, które

5 M. Đinđić, T. Cipek, Politički identiteti dalmatinskih Taljana 1860-1882, „Časopis za Savremenu Povijest" 2010, t. 42, nr 1, s. 221-222.

6 V. Maštrović, Odnos činovnika prema jezičnom pitanju u Dalmaciji u preporodno vrijeme, „Radovi Instituta JAZU u Zadru" 1961, t. 8, s. 46-47.

7 Por. A. Cetnarowicz, Odrodzenie narodowe w Dalmacji: od „slavenstva” do nowoczesnej chorwackiej i serbskiej idei narodowej, Kraków 2001. 
były ograniczone pod względem skali i wartości. Na uwagę zasługuje także informacja, że ze względu na poprawę warunków bytowych mieszkańców i powszechniejszy dostęp do służby zdrowia, w Dalmacji wzrosła liczba młodych ludzi. Ze zjawiskiem tym autorka identyfikuje zauważalny pod koniec wieku XIX wzrost radykalizacji podglądów społeczno-politycznych, a także wzmożoną emigrację z regionu, zwłaszcza w latach, gdy dochodziło tam do klęsk nieurodzaju w winnicach. W rezultacie, w kolejnych dekadach emigranci z Dalmacji stanowili większość w ramach chorwackiej diaspory, żyjącej poza granicami Europy.

W rozdziale piątym i szóstym autorka opisuje dalmatyńską specyfikę chorwackich i jugosłowiańskich ruchów politycznych z przełomu XIX i XX wieku, a także charakteryzuje meandry procesu industrializacji w regionie, zwracając uwagę na jego niejednoznaczne następstwa dla życia miejscowej ludności. W tym kontekście przywołany został np. dramat rodzin, które od pokoleń utrzymywały się z połowu i przetwórstwa ryb, a wskutek wejścia na miejscowy rynek czeskiej firmy produkującej konserwy (C. Wahranek) zostały pozbawione dochodu, zmuszone do przebranżowienia się lub emigracji. Sytuacja gospodarcza w Dalmacji była bardzo zła w porównaniu z innymi regionami monarchii. Najgorzej pod tym względem było na wsi, inwestycje lokowano głównie w Splicie, Šibeniku i Omišu.

Ostatni rozdział dotyczy czasów I wojny światowej i miesięcy bezpośrednio poprzedzających ten konflikt (1914). Autorka analizuje aktywność propagatorów idei jugosłowiańskiej na gruncie dalmatyńskim. Zwraca uwagę na wpływy czeskich działaczy narodowych wśród tamtejszych środowisk młodzieżowych chorwackich i serbskich. Pomija natomiast kwestie militarne, np. działania wojenne na Adriatyku czy udział mieszkańców Dalmacji w walkach. Powojenna charakterystyka ziem dalmatyńskich została omówiona ogólnikowo, zajęła niespełna jedną stronę.

Monografia autorstwa Boženy Vranješ-Šoljan to pierwsze opracowanie dziejów Dalmacji, oparte na drobiazgowej analizie materiału statystycznego i właśnie ten aspekt jest najważniejszy w kontekście rozważań nad miejscem recenzowanej publikacji w dotychczasowej refleksji naukowo-historycznej nad dziejami ziem chorwackich. Chociaż fragmenty dotyczące spraw politycznych nie wnoszą nic szczególnie odkrywczego, w powiązaniu z analizą statystyczną i rozważaniami nad tranzycją społeczno-gospodarczą, pozwalają w nowy sposób spojrzeć na historię Dalmacji. Pomimo potknięć o charakterze redakcyjnym jest to książka, która ze względu na specyficzną bazę źródłową z pewnością będzie punktem odniesienia dla wielu historyków regionalnych. 